\author{
Witold Filipczak (D) \\ https://orcid.org/0000-0001-5953-2480 \\ Uniwersytet Łódzki
}

\title{
PROTESTANCI W RZECZYPOSPOLITEJ 1777-1786 - MIĘDZY UNIĄ SIELECKĄ A KONFLIKTAMI (ZARYS PROBLEMATYKI)
}

\author{
ABSTRACT \\ Protestants in the Polish-Lithuanian Commonwealth in the Years 1777-1786: \\ Between the Union of Sielec and Conflicts (Introduction to the Topic)
}

This article examines the eighteenth century attempts to stimulate cooperation amog Protestants in the Polish-Lithuanian Commonwealth. Such endeavors were undertaken in the years 1775-1776 in Great Poland, while in 1777 the Union of Sielec between Protestants of Little Poland and Mazowsze was concluded. The union was intended to bring together Protestant congregations as religious entities without interfering in particular doctrinal and religious differences among them. In 1780, Protestants representing all parts of the Commonwealth met at a general council in Węgrów. Unfortunately, the existing differences among the groups prevailed and led to conflict. In effect, the followers of the Sielec Union failed to find a conciliatory platform with the Great Poland Protestants, who were backed by the Russian Ambassador Otto von Stackelberg. In 1782, the General Council of Węgrów was dissolved, which led to the collapse of the Sielec Union. The latter section of the article examines the political prosecution of Protestants, who were attacked by the Permanent Council and the Parliament of 1784 . Stackelberg's interference, as well as the attitude of the Polish king Stanislaus Augustus towards Protestants, have been also presented.

Keywords: Evangelics, Protestant synods, Union of Sielec, Permanent Council, Parliament of 1784

Słowa kluczowe: ewangelicy, synody protestanckie, unia sielecka, Rada Nieustająca, sejm 1784 r. 
„Sprawa dysydencka” w latach 1764-1768 doczekała się bogatej literatury przedmiotu ${ }^{1}$, natomiast dzieje polskich i litewskich ewangelików w kolejnych dekadach wzbudziły niewielkie zainteresowanie historyków. Po pierwszym rozbiorze zaczął się zaś nowy etap w dziejach polskiego protestantyzmu, o czym zadecydowało kilka czynników:

1) Ustawy sejmu z 1767/1768 r., który pod presją Rosji zniósł prawne ograniczenia protestantów co do swobody kultu i udziału szlachty niekatolickiej w życiu politycznym.

2) Osłabienie antydysydenckich nastrojów szlachty towarzyszących konfederacji barskiej.

3) Zmiana granic po I rozbiorze. Polska utraciła tereny, na których luteranizm był szczególnie silny - Prusy Królewskie i pólnocną Wielkopolskę. Gdańsk i Toruń pozostały w granicach Rzeczypospolitej, ale w niewielkim stopniu uczestniczyły w omawianych wydarzeniach.

Sejm rozbiorowy (1773-1775) przyniósł pewne ograniczenie praw szlachty niekatolickiej w stosunku do ustaw z 1768 r. Została ona pozbawiona możliwości uzyskiwania urzędów senatorskich. Liczbę potencjalnych posłów protestanckich i prawosławnych na sejm ograniczono do trzech - po jednym z Wielkopolski, Małopolski i Litwy. Zniesiono przewidziany w traktacie warszawskim z 1768 r. sąd mieszany (iudicium mixtum). Jego kompetencje przejęły Asesorie (Koronna i Litewska). Sprawy dotyczące dysydentów mieli rozstrzygać sędziowie - w równej liczbie katoliccy i niekatoliccy². W praktyce możliwość uzyskania funkcji poselskich przez niekatolików była początkowo tylko teorią, o czym świadczą obradujące sejmiki przedsejmowe w lipcu $1776 \mathrm{r}$. W powiecie wołkowyskim bezskutecznie o mandat zabiegat przedstawiciel ewangelicko-reformowanej rodziny Grabowskich $^{3}$. W Wielkopolsce nie powiodła się taka próba na sejmiku we Wschowie, choć protestanckiego kandydata popierał kasztelan poznański Józef Mielżyński. W instrukcji ziemi wschowskiej proponowano, by posłów „dysydenckich” mianował król, na wzór Inflant ${ }^{4}$.

$1 \quad$ Pisali na ten temat m.in.: A. Kraushar, Ksiaże Repnin i Polska w pierwszym czteroleciu panowania Stanistawa Augusta (1764-1768), t. I-II, Kraków 1900; K. Rudnicki, Biskup Kajetan Sottyk 1715-1788, Warszawa-Kraków 1906; C. Łubieńska, Sprawa dysydencka 1764-1766, Kraków-Warszawa 1911; G.T. Łu kow ski, The Szlachta and the Confederacy of Radom 1764-1767/68: A Study of the Polish Nobility, Roma 1977; J. D yg dała, Życie polityczne Prus Królewskich u schytku ich zwiąku z Rzecząpospolita w XVIII wieku, Warszawa-Poznań-Toruń 1984; Z. Zi i li ńsk a, Polska w okowach „systemu pótnocnego" 1763-1766, Kraków 2012.

2 Volumina Legum [dalej: VL], t. VIII, wyd. J. O hr yzk ko, Petersburg 1860, s. $47-48$ (Akt osobny); W. Gast pary, Historia protestantyzmu w Polsce od potowy XVIII wieku do pierwszej wojny światowej, Warszawa 1977, s. 58; J. Mi chalsk i, Sprawa wyboru postów dysydentów na sejm 1776 roku, [w:] Kultura staropolska - kultura europejska. Prace ofiarowane Januszowi Tazbirowi w siedemdziesiąta rocznice urodzin, red. S. Bylin a, Warszawa 1997, s. 273; W. Kri e g s e i s e n, Dysydenci i dyzunici w Rzeczypospolitej epoki stanistawowskiej, [w:] Stanistaw August i jego Rzeczpospolita. Dramat państwa, odrodzenie narodu, red. A. So 1tys, Z.Zielińska, Warszawa 2013, s. 60.

3 J. Michalski, op. cit., s. 279-280.

4 Instrukcja sejmiku we Wschowie z 15 VII 1776, Archiwum Główne Akt Dawnych w Warszawie [dalej: AGAD], Zbiór Popielów, sygn. [dalej: ZP] 129, k. 290; J. Michalsk i, op. cit., s. 278-279; P. Z ając, Gio- 
Ambicje Grabowskich, dążących do odegrania ważnej roli na sejmikach wołkowyskich, były widoczne w latach osiemdziesiątych XVIII w. W obradach poselskich w 1782 r. nie wzięli jednak udziału, gdyż część szlachty na czele z Michałem i Ksawerym Brzostowskimi napadła na ich stancję $e^{5}$ Na sejmiku deputackim w lutym 1783 r. urzędnicy wołkowyscy, m.in. podkomorzy Mikołaj Bułharyn, oskarżyli generałów Jana Jerzego i Michała Grzegorza Grabowskich o sprowadzenie na sejmik wojska i niedopuszczenie szlachty do zwykłego miejsca obrad ${ }^{6}$. Pierwszy raz w tamtym czasie protestant został posłem w $1784 \mathrm{r}$. W Wolkowysku powierzono tę funkcję generałowi inspektorowi J.J. Grabowskiemu . W 1767 r. był on marszałkiem konfederacji dysydentów litewskich zawiązanej 20 marca w Słucku ${ }^{8}$. W 1786 r. posłem wołkowyskim został Paweł Grabowski, od 1784 r. starosta grodowy wołkowyski, co miało istotne znaczenie w staraniach o funkcję?. W Koronie pierwszego ewangelika na posła, z województwa gnieźnieńskiego, wybrano na sejmiku w Środzie w listopadzie 1790 r. Był nim Adam Feliks Bronikowski, patron ewangelicko-reformowanego zboru w Żychlinie ${ }^{10}$. W tym samym czasie posłem wołkowyskim został krajczy litewski Zygmunt Grabowski ${ }^{11}$.

vanni Andrea Archetti i Stanistaw August Poniatowski. Obraz króla i wzajemnych relacji w depeszach nuncjusza do sekretu stanu Stolicy Apostolskiej z lat 1776-1784, „Kwartalnik Historyczny” R. CXXIII, 2016, nr 2, s. 284.

5 Relacja o sejmiku wołkowyskim, AGAD, ZP 126, k. 192-192v; Michał Grabowski do króla, bez daty, Biblioteka Czartoryskich w Krakowie, rkps [dalej: BCz] 663, s. 163-164; W. Fili i c z a k, Życie sejmikowe prowincji wielkopolskiej w latach 1780-1786, Łódź 2012, s. 91.

6 Urzędnicy wołkowyscy do króla, b.d., oraz oświadczenie urzędników i szlachty wołkowyskiej z 3 II 1783, AGAD, ZP 130, s. 44-46; A. Kalen ki ew ic zów na, Rozktad partii Tyzenhauza na tle sejmików litewskich, [w:] Ksiegga pamiątkowa Kota Historyków Stuchaczy USB w Wilnie, Wilno 1933, s. 140; W. Filipczak, Ekonomie litewskie w polityce sejmikowej Stanistawa Augusta po upadku Antoniego Tyzenhauza (1780-1783), „Przegląd Nauk Historycznych” R. V, 2006, nr 1(9), s. 270-271.

7 Uwiadomienie o stancyach... senatorow, ministrow i postow na Seym ordynaryiny grodzieński w roku 1784. zgromadzonych, b.m. [1784], s. 14 (druk w: AGAD, ZP 128, k. 45 i n.); A. Kale n ki e wic zów na, op. cit., s. 140 .

8 Jan Grabowski do [Aleksandra M.] Sapiehy, Słuck 29 III 1767, Lietuvos mokslų akademijos Vrublevskiu biblioteka, fondas 139, byla 1254, k. 54-55; G.T. Łu kow ski, op. cit., s. 86. Zob. też: W. Ko n o p czyński, Grabowski Jan Jerzy, [w:] Polski stownik biograficzny, t. 8, Wrocław 1960, s. 494.

9 A. Danilczyk, W kregu afery Dogrumowej. Sejm 1786 roku, Warszawa 2010, s. 110.Zob. też: S. He rbst, Grabowski Pawet, [w:] Polski stownik biograficzny, t. 8, s. 506-507.

10 W. Kriegse is en, Zbór ewangelicko-reformowany (kalwiński) w Żychlinie koto Konina, „Odrodzenie i Reformacja w Polsce" 1993, t. 37, s. 111; R. B ut ter wick, Polska rewolucja a Kościót katolicki 1788-1792, tłum. M. Ugn iewski, Kraków 2012, s. 691. O działaniach A. Bronikowskiego w związku z sejmikiem kaliskim w lutym 1792 r. zob.: W. Szczygi iels ki, Referendum trzeciomajowe. Sejmiki lutowe 1792 roku, Łódź 1994, s. 90-91.

11 Lietuvos Dzidžiosios Kunigaikštystés seimeliu instrukcijos (1788-1790), parengè R. Ju rg a i t is, A. S ta n kevič, A. Verbickienè, Vilnius 2015, s. 268; R. Butterwick, op. cit., s. 691. 
Po I rozbiorze wzrosła aktywność protestantów i dążenie do ściślejszej współpracy, co dotyczyło kontaktów między ewangelikami augsburskimi i reformowanymi, a także relacji w ramach obu wyznań. W przypadku kalwinizmu każda z prowincjonalnych Jednot (Litewska, Małopolska i Wielkopolska) była samodzielna i niezależna od pozostałych ${ }^{12}$.

Przez wiele dekad nie odbywały się protestanckie synody generalne. Ostatni w czasach saskich obradował w Gdańsku w 1728 r. Ich rolę częściowo przejęły synody prowincjonalne, ale i te zbierały się rzadko. Pod koniec epoki saskiej odbyły się w Wielkopolsce w 1756 (w Lesznie) i 1762 r. ${ }^{13}$ Po I rozbiorze sytuacja zmieniła się. W końcu lipca 1775 r. szlacheccy seniorzy obu wyznań ewangelickich w Wielkopolsce zaprosili zbory w prowincji, także warszawskie, do wydelegowania przedstawicieli na synod. Zebrał się on w Lesznie w dniach 4-9 września 1775 r., ale jako luterański. Obradom przewodniczył generał August Stanisław Goltz ${ }^{14}$. W 1767 r. był on marszałkiem dysydenckiej konfederacji w Toruniu ${ }^{15}$. Wielkopolski konsystorz dla ewangelików augsburskich wybrano 6 września 1775 r. Planowano też ustanowienie, w przyszłości, analogicznego organu dla obu wyznań w prowincji. Projekt unii obu wyznań przekazano we wrześniu 1775 r. władzom Jednoty Wielkopolskiej ${ }^{16}$. Decyzje synodu nie zadowoliły przedstawicieli luterańskiego zboru warszawskiego, którzy działali zgodnie z udzielonymi im instrukcjami ${ }^{17}$.

Ewangelicy warszawscy nie wzięli udziału w kolejnym wielkopolskim synodzie w Lesznie, który zebrał się w styczniu 1776 r. Równolegle z luterańskim zebrał się synod Jednoty Wielkopolskiej. Doszło do wspólnych obrad. Powołano komisję mającą przygotować akt unii, który następnie przyjęto. Planowano utworzenie konsystorza generalnego dla całej Rzeczypospolitej. Ustalono, że co roku w marcu będą zbierać się w Lesznie wspólne synody ewangelików wielkopolskich ${ }^{18}$. Powyższej koncepcji niechętna była Jednota Małopolska, której delegaci uczestniczyli w obradach Wielkopolan we wrześniu 1775 i w styczniu 1776 r. ${ }^{19}$ Przedstawiciele obu wyznań mieli spotkać się ponownie na synodzie w Lesznie,

12 W. Kriegseisen, Dysydenci i dyzunici..., s. 53.

13 W. Krieg se is en, Ewangelicy polscy i litewscy w epoce saskiej (1696-1763). Sytuacja prawna, organizacja i stosunki międzywyznaniowe, Warszawa 1996, s. 162.

14 W. Gastpary, op. cit., s. 60-61.

15 A.S. Goltz został marszałkiem konfederacji toruńskiej po śmierci brata - Jerzego Wilhelma (24 IV 1767): J. Dygdała, op. cit., s. 198.

16 Projekt aktu unii z września 1775 r., Archiwum Państwowe w Poznaniu [dalej: APP], Akta Braci Czeskich, sygn. [dalej: ABCz] 1984, s. 1-19; W. Gastpary, op. cit., s. 61.

17 W. Gastpary, op. cit., s. 61-63.

18 Ibidem, s. 64-65. Wielkopolskie synody prowincjonalne obu wyznań odbywały się w Lesznie w latach 1775-1778 i 1781-1782. W 1779 r. miejscem obrad była Kargowa. W. Kri egse is en, Ewangelicy polscy..., s. 162. W sierpniu 1785 r. wielkopolski synod prowincjonalny obradował we Wschowie. AGAD, Zbór Ewangelicko-Augsburski w Warszawie, sygn. [dalej: ZEAW] 15, s. 1-46.

19 Kongregacje i synody małopolskie 1775, 1776, 1781, 1783-1787 i 1790 r., Biblioteka Uniwersytecka w Warszawie, rkps [dalej: BUW] 599, k. 1, 3-3v, 5, 7, 9v, 11. 
którego początek wyznaczono na 16 lipca $1776 \mathrm{r}^{20}{ }^{20}$ Podczas wspólnych obrad przedstawicieli obu ewangelickich Kościołów wielkopolskich zajęto się m.in. sprawą opracowania protestanckiego prawa kościelnego. Przygotowania projektu podjął się, z inicjatywy A.S. Goltza, Heinrich Gottfried Scheidemantel, profesor prawa w Jenie ${ }^{21}$. Na synodach w Lesznie w marcu 1777 r. oba wyznania zgodziły się zwołać na 9 czerwca tegoż roku wspólny synod. Było to zgodne z propozycją A.S. Goltza, który chciał, aby sformułowano stanowisko wobec planowanej unii zborów warszawskich z Jednotą Małopolską. O takim zamiarze warszawscy protestanci pisali w liście z 23 listopada 1776 r., skierowanym do zborów małopolskich. Goltz był niechętny projektowi. Twierdzil, że zbory warszawskie uzurpują sobie prawo do występowania w imieniu całego mieszczaństwa. Odrzucał, jako sprzeczne z dotychczasowymi zwyczajami i przepisami, postulaty miejskich zborów wielkopolskich, które domagały się świeckich seniorów okręgowych ze stanu miejskiego ${ }^{22}$. Warszawa znajdowała się w prowincji wielkopolskiej, ale była związana ze zborami w podlaskim Węgrowie ${ }^{23}$, położonym w prowincji małopolskiej, choć kościelnie należącym do Litwy.

Do porozumienia ewangelików warszawskich z Jednotą Małopolską doszło w dniach 1-2 maja 1777 r. w kościele kalwinistycznym w Sielcu koło Staszowa, gdzie podpisano akt unii Kościołów protestanckich obojga wyznań w księstwie mazowieckim z Kościołami prowincji małopolskiej ${ }^{24}$. „Dyrektorem” synodu był wówczas podpułkownik Stanisław Ożarowski, zaś sekretarzem ks. Andrzej Gajewski ${ }^{25}$. Przewidywano, że na synodach votum decisivum dysponować będzie każdy z trzech stanów: szlachecki („rycerski”), duchowny i miejski („cywilny”). Decyzje miały zapadać większością dwóch głosów. Zasada ta nie obowiązywała jednak w „partykularnych sprawach lub interesach”, w których oddawano tyle głosów, ile „zgromadzeń" było reprezentowanych na obradach - wspólne wotum składali patron zboru, duchowny („minister”) i prezbiterowie ${ }^{26}$. Wbrew wcześniejszej praktyce przewidziano powołanie seniora „stanu cywilnego", którym został Piotr Tepper starszy. Po powrocie do Warszawy miał on być „prezentowany” obu zgromadzeniom ewangelickim przez delegatów zborowych - Samuela Kahla i Samuela Horna. Senior mieszczański miał sprawować funkcję w Warszawie, przy zachowaniu alternaty między zborami obu wyznann ${ }^{27}$. Funkcję dyrektora

20 Jan Aleksander Cassius do starszych zboru reformowanego w Toruniu, Leszno 10 VI 1776, APP, ABCz 2504, s. 1-3.

21 W. Gastpary, op. cit., s. 65-66.

22 Ibidem, s. 66-68.

23 W. S moleński, Mieszczaństwo warszawskie w końcu wieku XVIII, wyd. 2, Warszawa 1976, s. 44.

24 Akt unii Kościołów protestanckich obojga wyznań w księstwie mazowieckim będących z kościołami prowincji małopolskiej, AGAD, ZEAW 12, s. 2-7; W. Gastpary, op. cit., s. 68; W. Kriegseisen, Zbór kalwiński w Sielcu koto Staszowa, „Odrodzenie i Reformacja w Polsce” 1990, t. 35, s. 166.

25 Akta i uchwały synodu prowincjalnego... roku 1777 w Sielcu odprawionego, BUW 600, s. 15, 20.

26 Akt unii..., AGAD, ZEAW 12, s. 3; W. Gastpar y, op. cit., s. 68-69.

27 Akt unii..., AGAD, ZEAW 12, s. 4-5. 
synodu zastrzegano dla przedstawiciela „stanu rycerskiego". Przewidywano głos na synodzie dla zborów bez własnych kościołów i pastorów (m.in. w Krakowie, Lublinie i Staszowie). Decyzję w sprawie zwołania synodu powinni uzgadniać seniorzy wszystkich trzech stanów. Zastrzegano, że mają się one odbywać corocznie w pierwszą niedzielę po święcie Trójcy Świętej. W nagłej potrzebie seniorzy mogli zwołać synod nadzwyczajny ${ }^{28}$. Synod rezerwował sobie prawo „odmienienia seniorów, gdyby ważne do tego były przyczyny”. Akta synodalne miały być podpisywane „viritim od wszystkich przytomnych”29. Unia sielecka łączyła wyznania pod względem administracyjnym; nie ingerowała w kwestie doktryny i porządku kościelnego. Utworzono wspólny złożony z sześciu osób konsystorz, w skład którego wchodziły po dwie osoby z każdego ze stanów. Na czele stało dwóch prezesów: duchowny i szlachecki, którzy mieli urzędować przy zachowaniu alternaty. Jednym z przedstawicieli duchowieństwa był luterański pastor w Warszawie ${ }^{30}$.

Kolejny synod małopolsko-mazowiecki obradował 21-24 czerwca 1778 r. w Piaskach (koło Lublina). Obradom przewodniczył starosta omelnicki Teodor Suchodolski, patron zboru reformowanego w Piaskach. Piotr Tepper, senior „stanu cywilnego”, zaprezentował akt akcesu do unii niemieckojęzycznej szlachty (18 luteranów, 1 reformowany) z województwa mazowieckiego ${ }^{31}$. Do unii przystąpiło, 22 czerwca 1778 r., także ewangelicko-augsburskie zgromadzenie lubelskie, które na synodzie było reprezentowane przez Jana Dawida Heisslera i Carla Albrechta Hildenbrandta ${ }^{32}$. Delegaci lubelscy przedstawili obawy swoich współwyznawców związane z kanonem poprzedniego synodu, który dotyczył wspólnego użytkowania przez wiernych obu wyznań luterańskiego kościoła w Piaskach. Zmieniono poprzednią decyzję, zastrzegając, że dotyczy ona okresu dziesięciu lat, w którym to reformowani powinni wybudować sobie nowy kościół ${ }^{33}$. Na synodzie w $1778 \mathrm{r}$. powołano luterańskich seniorów - duchownego i świeckiego, czego nie uczyniono rok wcześniej. Zostali nimi podkomorzy Goltz (ze „stanu rycerskiego”) i ks. Gottlieb Teofil Ringeltaube, warszawski pastor i asesor wspólnego konsystorza. Funkcję konseniora

${ }_{28}$ Akt unii..., AGAD, ZEAW 12, s. 5; W. Gastpary, op. cit., s. 69.

29 Akt unii..., AGAD, ZEAW 12, s. 6.

30 Ustanowienie Konsistorza wspólnego prowincji małopolskiej zjednoczonej... z zgromadzeniami obojga wyznań w Księstwie Mazowieckim..., BUW 602, k. 7-7v (także: BUW 600, s. 8-9); W. G a s tp a r y, op. cit., s. 70 .

31 Akta i uchwały synodu... w Piaskach w dniach 21-24 VI 1778, AGAD, ZEAW 12, s. 12; Przystęp ww. rycerstwa... w księstwie mazowieckim do unii..., BUW 600, s. 31-34; W. Kłacze w ski, Zbory różnowiercze w Piaskach i ich patronowie, „Rocznik Lubelski” 1979, t. 21, s. 73-74.

32 Akta i uchwały synodu w Piaskach... i akces do unii... uczyniony od zgromadzenia lubelskiego... 22 VI 1778, AGAD, ZEAW 12, s. 12, 29.

33 Akta i uchwały synodu w Piaskach..., AGAD, ZEAW 12, s. 12-13. Kościół reformowany z Piaskach został odbudowany w latach 1783-1785: W. Kłaczewski, op. cit., s. 74; W. Kriegse is en, Ewangelicy polscy..., s. 62 . 
duchownego, utworzoną rok wcześniej ${ }^{34}$, otrzymał pastor lubelski ks. Tobiasz Bauch ${ }^{35}$. Obowiązki szlacheckiego seniora wyznania augsburskiego dla Mazowsza powierzono pułkownikowi Petrowi Königfelsowi. Synod wyłonił trzech kandydatów, którzy mieli reprezentować ewangelików w Asesorii Koronnej ${ }^{36}$. Wobec absencji wielu przedstawicieli kalwińskiej szlachty małopolskiej postanowiono nałożyć na każdego nieobecnego karę wysokości 100 zł, a dochody z tego tytułu zamierzano przeznaczyć na potrzeby kościelne i edukacyjne zborów małopolskich. Przyjęto przepisy dotyczące dzieci z mieszanych małżeństw protestantów różnych konfesji ${ }^{37}$. Synod poprosił ewangelików litewskich o zgodę na przyłączenie augsburskiego zboru w Węgrowie do Mazowsza ${ }^{38}$. Skierowano list do warszawskich luteranów. Wyrażano w nim zdziwienie z powodu żądania, by w przyszłości sprawy, które mają być tematem synodu, były umieszczane w pismach zapraszających do udziału w nim. Wskazywano, że sami zainteresowani mogą umieścić interesujące ich problemy w instrukcji dla swoich delegatów ${ }^{39}$.

Za przykładem ewangelików koronnych poszli protestanci litewscy. Na 3 lipca $1778 \mathrm{r}$. zwołano do Kiejdan wspólny synod. Wcześniej, 16 lutego 1778 r., w Kownie zebrali się przedstawiciele kilku zborów luterańskich, by uzgodnić postulaty. Do pełnego zjednoczenia jednak nie doszło, gdyż w synodzie nie wzięły udziału: część zboru kowieńskiego oraz luterańskie zbory z Wilna i Słucka, które zadeklarowały samodzielnośćc ${ }^{40}$.

Nie były to jedyne spory wśród polskich protestantów. W sierpniu 1778 r. przedsejmowy sejmik ziemi łomżyńskiej postulował uspokojenie kłótni między dysydentami świeckimi i duchownymi ${ }^{41}$. Niejasny jest kontekst tego apelu. Unia sielecka była niechętnie przyjęta przez szlachtę luterańską w Wielkopolsce, zwłaszcza przez A.S. Goltza. Luterańscy seniorzy generalni i okręgowi, a także członkowie konsystorza zgłosili zastrzeżenia do aktu unii. Zarzucali zborowi warszawskiemu, że bezpodstawnie występuje w imieniu wszystkich luteranów na Mazowszu, gdzie istniał jeszcze zbór w Iłowie ${ }^{42}$. Do konfliktów

34 Akt unii..., AGAD, ZEAW 12, s. 4-5.

35 Akta i uchwały synodu w Piaskach..., AGAD, ZEAW 12, s. 14.

36 Akta i uchwały synodu w Piaskach..., AGAD, ZEAW 12, s. 17-18. Kandydatami do Asesorii byli: generał major Adam Wielowieyski, szambelan Paweł Stryjeński i pułkownik Samuel Ożarowski.

37 Akta i uchwały synodu w Piaskach..., AGAD, ZEAW 12, s. 15-16.

38 Akta i uchwały synodu w Piaskach..., AGAD, ZEAW 12, s. 21. Sprawę tę uregulował synod generalny w Węgrowie w 1780 r. Węgrowski zbór reformowany pozostał nadal w Jednocie Litewskiej. Akta i ustawy synodu generalnego w zebraniu trzech prowincji... 1780 roku, BUW 603, k. 6.

39 Synod w Piaskach do warszawskiego zgromadzenia konfesji augsburskiej, 24 VI 1778, AGAD, ZEAW 12, s. 30 .

40 W. Gastpary, op. cit., s. 71-72.

41 Instrukcja sejmiku w Łomży z 17 VIII 1778, Biblioteka PAU i PAN w Krakowie, rkps [dalej: BPAU] 8332, k. 411v; W. Fili p czak, Sejm 1778 roku, Warszawa 2000, s. 135.

42 W. Gastpary, op. cit., s. 71-72. Ewangelicko-augsburski zbór w Iłowie (województwo rawskie) powstał 
doszło też wśród protestantów wielkopolskich. Należy pamiętać, że Antoni Małachowski, poseł łomżyński w $1778 \mathrm{r}$., dwa lata wcześniej posłował na sejm z powiatu poznańskiego ${ }^{43}$. Wielkopolski synod z lipca 1778 r. wykluczył z udziału w ciałach kościelnych Abrahama Emanuela Wolffa ${ }^{44}$, generalnego medyka wojskowego. Napisał on broszurę związaną ze sporami finansowymi między mieszczanami a szlacheckimi seniorami zborów wielkopolskich $^{45}$. Na synodzie w Lesznie w lipcu 1778 r. doszło też do konfliktu „między rycerstwem i niektóremi duchownemi reformowanemi z okazji wyszłego za granicą skryptu pokój wewnętrzny wzruszającego”. Sprawa trafila do Asesorii, a kwestie dotyczące „rządu kościelnego" zostały dekretem kompromisarskim odesłane do decyzji synodu generalnego ${ }^{46}$. We wrześniu 1778 r. Rada Nieustająca zajmowała się skargą duchownych i starszych zborów reformowanych na szlachtę tegoż wyznania o „uciążliwości w kontrybucjach” ${ }^{\text {. }}$.

Sprawa ta była istotna dla podjęcia przez protestantów wielkopolskich starań o zwołanie synodu generalnego. Mieli w nim uczestniczyć przedstawiciele ewangelików ze wszystkich trzech prowincji: Wielkopolski, Małopolski z Mazowszem i Litwy. O działaniach szlacheckich seniorów wielkopolskich pułkownik Jan Malicki, małopolski senior „stanu rycerskiego" (reformowany), informował 6 sierpnia 1779 r. P. Teppera. Malicki wcześniej rozmawiał na ten temat z A.S. Goltzem. W czasie dyskusji pojawiły się różnice zdań, a dalszymi uzgodnieniami powinny zająć się osoby wydelegowane przez oba synody prowincjonalne. Malicki uzyskał zgodę A.S. Goltza, by na synodzie generalnym votum decisivum otrzymali delegaci ze „stanu cywilnego”. Pułkownik apelował do P. Teppera, żeby Mazowszanie wybrali „osoby zdatne” reprezentujące oba stany (szlachtę i mieszczan), które to osoby miały zostać potwierdzone przez synod prowincjonalny ${ }^{48}$. Malicki prosił także, aby pomyślano nad stworzeniem funduszu dla osób reprezentujących protestantów w Asesorii. W innej

w 1775 r. P. Fija łkow ski, Historia parafii ewangelicko-augsburskiej w Itowie w XVIII-XIX w., „Odrodzenie i Reformacja w Polsce" 1994, t. 38, s. 112.

43 Series senatorow, ministrow y postow zasiadaiacych na Seymie 1776. roku, [w:] Dyaryusz Seymu ordynaryinego pod związiem konfederacyi generalney oboyga narodów agitującego się, wyd. A. Cie cis zo wski, Warszawa 1776; Instrukcja poselska ziemi łomżyńskiej z 17 VIII 1778, BPAU 8332, k. 410; H. D y m n icka-Wołoszyńska, Matachowski Antoni, [w:] Polski stownik biograficzny, t. 19, Wrocław 1974, s. 388.

44 W. Gastpary, op. cit., s. 73.

45 A.E. Wolff, Usprawiedliwienie Medyka Generalnego Woysk..., b.m. 1778 [druk w: BCz 756 - tam także (s. 79-80) list A.E. Wolffa ze skargami na uzurpacje szlachty dysydenckiej]; W. Filipczak, Sejm 1778, s. 135.

46 Kopia listu seniorów wielkopolskich pisanego do synodu prowincji małopolskiej złączonej z księstwem mazowieckim w Sielcu ultimis augusti et $1^{\mathrm{ma}} 7$ bris 1779 roku odprawującego się, AGAD, ZEAW 12, s. 62 63.

47 Protokół Rady Nieustającej z 15 IX 1778, AGAD, tzw. Metryka Litewska, dział VII, sygn. [dalej: ML VII] 20, s. 243; W. Filipczak, Sejm 1778, s. 135.

48 Ekscerpt listu... Malickiego pułkownika pisanego do... Piotra Teppera z Malic d. 6 augusti 1779, AGAD, ZEAW 12, s. 39-40. 
sytuacji konieczne będzie zobowiązanie każdego ewangelickiego szlachcica do pełnienia tej funkcji, która byłaby powierzana także osobom bez odpowiednich kwalifikacji ${ }^{49}$.

Latem 1779 r. szlacheccy seniorzy z Wielkopolski wysłali list do synodu prowincjonalnego małopolsko-mazowieckiego, który miał się zebrać 28 sierpnia w Sielcu. Wyjaśniano w nim, że pismo nie mogło zostać wystosowane przez wielkopolski synod prowincjonalny, gdyż ten rozpoczynał obrady 24 sierpnia w Kargowej - zabrakłoby więc czasu na korespondencję między obu zgromadzeniami ${ }^{50}$. Seniorzy wielkopolscy uważali, że po ustawach z 1775 r. zwołanie synodu generalnego trzech prowincji stało się niezbędne dla uporządkowania sytuacji w kościołach ewangelickich. Powołano się na zgodę sandomierską z $1570 \mathrm{r}$. i zbierające się po niej wspólne synody. Za priorytetową sprawę seniorzy uznali przyjęcie projektu prawa kościelnego, w którym miano pomijać sprawy dogmatyczne ${ }^{51}$. Synod generalny powinien się zebrać pod koniec stycznia 1780 r. w Toruniu. Proponowane miejsce obrad przedstawiano, co brzmi kuriozalnie, jako „najbliższe” dla Litwinów. Apelowano, aby w Sielcu wybrano „z każdego stanu” i z każdej konfesji po dwóch deputowanych. W synodzie mogli uczestniczyć jako pełnoprawni członkowie seniorzy generalni. Delegaci mieli zostać zaopatrzeni w instrukcję i plenipotencję. Za cele synodu stawiano: przyjęcie prawa kościelnego, odnowienie zgody sandomierskiej między wyznaniami i wyeliminowanie sporów w społeczności dysydentów ${ }^{52}$.

W tej sytuacji synod małopolsko-mazowiecki obradujący w Sielcu w dniach 28 sierpnia-1 września 1779 r., pod „dyrekcją” [Michała?] Dołęgi, podpułkownika w wojsku koronnym ${ }^{53}$, w dużej mierze poświęcony był przygotowaniom do synodu generalnego. Odpowiedzi na list seniorów wielkopolskich mieli udzielić seniorzy stanu rycerskiego. Do dalszej korespondencji w sprawie synodu generalnego wyznaczonych zostało 12 osób. Na miejsce jego obrad zaproponowano Węgrów („gdy Toruń zbyt jest odległy”) ${ }^{54}$. Wybrani zostali delegaci na synod generalny, przy czym uwzględniano parytet obu wyznań. „Stan rycerski” miały reprezentować cztery osoby, duchowny - dwie, zaś „cywilny” - piecć. Deklarowano napisanie listu do prowincji litewskiej, aby zachęcić ją do udziału w obradach. Zaznaczono jednak, że gdyby Litwini uchylili się od niego, Małopolanie i tak wezmą udział w synodzie generalnym ${ }^{55}$. Delegaci zostali zaopatrzeni w instrukcję, w której wyszczególniono trzy punkty: 1) nakazywano im „do niczego nie przystępować”, co mogło szkodzić unii obojga

49 Ekscerpt listu... Malickiego..., AGAD, ZEAW 12, s. 40-41; W. Kriegseisen, Dysydenci i dyzunici..., s. 60.

50 Kopia listu seniorów wielkopolskich..., AGAD, ZEAW 12, s. 64.

51 Ibidem, s. 61-62.

52 Ibidem, s. 63-64.

53 Akta i uchwały synodu małopolskiej prowincji z księstwem mazowieckim... w Sielcu diebus 28, 29, 30,31 aug. et $1^{\text {ma }} 7$ bris 1779 roku, AGAD, ZEAW 12, s. 51.

54 Akta i uchwaly synodu... w Sielcu... 1779 r., AGAD, ZEAW 12, s. 51-52.

55 Ibidem, s. 53. 
wyznań w Małopolsce i na Mazowszu; 2) w sprawach odesłanych wyrokiem kompromisarskim na synod generalny delegaci mieli się zgodzić na rozstrzygnięcia, które były zgodne ze stosowaną w prowincji praktyką i uchwalonymi niedawno kanonami, nawet jeśli „nie stosowały się we wszystkim do dawniejszych synodów g[enera]lnych ustaw”; 3 ) zastrzegano, że we wszystkich sprawach wota prowincji małopolskiej z Mazowszem muszą mieć taką samą wagę jak głosy prowincji wielkopolskiej ${ }^{56}$.

W sprawach niezwiązanych z synodem generalnym na uwagę zasługuje wyrażenie zgody na żądanie delegatów zgromadzeń warszawskich w sprawie wzięcia przez nie w administrację kasy konsystorskiej ${ }^{57}$. Wyznaczono nowych asesorów do jurysdykcji konsystorskiej na miejsce osób, których kadencja się skończyła. Skorygowano także, uchwalone rok wcześniej, przepisy dotyczące ewangelickich małżeństw mieszanych ${ }^{58}$. Synod polecił, aby konsystorz pozwał zbór krakowski, napominany wcześniej m.in. na synodzie w Piaskach ${ }^{59}$, z powodu odprawiania w kościołach katolickich chrztów i ślubów. Praktykę taką uznano za szkodliwą dla „wolności religii naszej” ${ }^{60}$. Starania o znalezienie funduszy na pensje dla przedstawicieli dysydentów w Asesorii Koronnej zostały powierzone pułkownikowi J. Malickiemu, który jesienią 1779 r. próbował skłonić protestanckich mieszczan do prowadzenia konsultacji mających na celu przyjęcie na siebie zobowiązań w tej sprawie ${ }^{61}$.

Do synodu generalnego, reprezentującego zbory protestanckie z Wielkopolski, Małopolski, Mazowsza i Litwy, doszło przeszło pół roku później, niż zaproponowali to seniorzy wielkopolscy w liście do synodu w Sielcu. Obrady, które rozpoczęły się 28 sierpnia $1780 \mathrm{r}$. w Węgrowie, otworzyli ks. G. Ringeltaube i senior generalny Jednoty Litewskiej generał major Grzegorz Grabowski z Konopnicy. Na dyrektora synodu został wybrany generał A.S. Goltz. Wyłoniono osobnych pisarzy synodalnych dla każdej prowincji. Delegatów litewskich wybrano na synodzie w Izabelinie, który zebrał się 6 lipca. Funkcje pisarzy pełnili: kapitan Jerzy Kornatowski (Wielkopolska), ks. Andrzej Gajewski (Małopolska i Mazowsze) i ks. Tobiasz Grotkowski, konsenior dystryktu podlaskiego (Litwa) ${ }^{62}$. W obradach uczestniczył także, jako reprezentant Stanisława Augusta, pułkownik Kauffmann. Jednym

56 Kopia instrukcji ww. delegatom z małopolskiej prowincji i z księstwa mazowieckiego na synod g[enera]lny danej, w Sielcu, na synodzie, d. 30 aug. 1779 roku, AGAD, ZEAW 12, s. 48-49.

57 Akta i uchwały synodu... w Sielcu... 1779, AGAD, ZEAW 12, s. 53-54.

58 Ibidem, s. 54-56.

59 Akta i uchwały synodu w Piaskach..., AGAD, ZEAW 12, s. 17.

60 Akta i uchwały synodu... w Sielcu... 1779, AGAD, ZEAW 12, s. 57.

${ }_{61}$ Ekscerpt listu... pułkownika Malickiego de 28 octobr. 1779, AGAD, ZEAW 12, s. 72 . Zgromadzenia warszawskie w 1781 r. przeznaczyły na ten cel 1008 zł. Akta i uchwały synodu... 1781 w Sielcu, BCz 753, s. 612 .

62 Diariusz synodu generalnego obojej konfesji z trzech prowincji w Węgrowie dnia 28 aug. anno 1780 zaczętego, BCz 753, s. 337-338 (także: BUW 603, k. 9); W. Gast par y, op. cit., s. 75. 
z głównych tematów był projekt zbioru praw kościelnych, usilnie forsowany przez dyrektora synodu ${ }^{63}$. Na życzenie A.S. Goltza projekt przygotował wspomniany H.G. Scheidemantel, profesor prawa w Jenie. Odbyło się to zresztą poza oficjalnymi strukturami kościelnymi, które podejmowały własne prace w tym zakresie. Goltz próbował uzyskać poparcie dla projektu w Petersburgu. Na polecenie Katarzyny II Nikita Panin zalecił ambasadorowi w Warszawie Ottonowi M. von Stackelbergowi wsparcie inicjatywy ${ }^{64}$. W czasie synodu węgrowskiego projekt nowego prawa kościelnego wywołał kontrowersje. Zgłoszono dwie propozycje kanonu w sprawie przyjęcia go za prawo. Pierwszą przedstawił A.S. Goltz, drugą podpułkownik Stanisław Ożarowski (reprezentant Małopolski). Obie prowincje koronne projekt zaakceptowały, zaś przedstawiciele Jednoty Litewskiej wzięli go „ad referendum do braci swoich" ${ }^{65}$. Przyjęto projekt z zastrzeżeniem, że o zakresie, w którym jego przepisy mają obowiązywać, decydować ma synod prowincjonalny ${ }^{66}$.

Dużo czasu w Węgrowie zajęło rozstrzygnięcie sporów wśród ewangelików wielkopolskich, które to spory zostały odesłane wcześniej przez wyrok kompromisarski na synod generalny. Zajmowano się dekretem synodu w Lesznie (z 6 lipca 1778 r.) w sprawie A.E. Wolffa ${ }^{67}$. W kwestii konfliktu wielkopolskich duchownych reformowanych z tamtejszą szlachtą synod generalny wydał decyzję korzystną dla „stanu rycerskiego" ${ }^{68}$. Potępiono zbory litewskie w: Wilnie, Słucku, częściowo w Kownie, które nie przystąpiły do porozumienia z reformowanymi. Odczytano akta synodu, który zebrał się 14 lutego $1780 \mathrm{r}$. w Wilnie, gdzie reprezentowane były wspomniane zgromadzenia. Synod generalny zakwestionował powołany przez nie odrębny konsystorz ${ }^{69}$. Dokonano rozgraniczenia jurysdykcji prowincji małopolsko-mazowieckiej i wielkopolskiej. Ta ostatnia obejmowała trzy województwa Wielkopolski właściwej, oba kujawskie (bez ziemi dobrzyńskiej) i województwo sieradzkie na zachód od Warty, a więc z ziemią wieluńską ${ }^{70} .7$ września jednogłośnie wybrano Aleksandra Unruga, starostę hamersztyńskiego, na seniora generalnego trzech prowincji ${ }^{71}$. Na sesji w ostatnim dniu synodu ( 8 września 1780 r.) przyjęto dość ogólnikowy kanon dotyczący obowiązków seniora generalnego trzech prowincji ${ }^{72}$.

63 Diariusz synodu generalnego... 1780, BCz 753, s. 338-341.

64 W. Gastpary, op. cit., s. 75-76.

65 Diariusz synodu generalnego... 1780, BCz 753, s. 340-341 (także: BUW 603, k. 10).

66 Akta i ustawy synodu generalnego... 1780 r., BUW 603, k. 5-5v; W. G a s tp a r y, op. cit., s. 77.

67 Diariusz synodu generalnego... 1780, BCz 753, s. 341-342 (także: BUW 603, k. 11).

68 Diariusz synodu generalnego... 1780, BCz 753, s. 341-343, 345, 348.

69 Akta i ustawy synodu generalnego... 1780 r., BUW 603, k. 5v-6; Diariusz synodu generalnego... 1780, BCz 753, s. 344; W. Gas tpary, op. cit., s. 77.

70 Akta i ustawy synodu generalnego... 1780 r., BUW 603, k. 6.

71 Diariusz synodu generalnego... 1780, BCz 753, s. 346; W. Ga s t p a r y, op. cit., s. 77.

72 Akta i ustawy synodu generalnego... 1780 r., BUW 603, k. 6v; Diariusz synodu generalnego... 1780, BCz 753, s. 348 (także: BUW 603, k. 13). 
W tym czasie doszło do konfliktu konsystorza z kolegium kościelnym zboru luterańskiego w Warszawie w związku z przygotowaną przez nie ordynacją kościelną. Goltz i Unrug polecili skorygować ją oraz nakazali zborom warszawskim opodatkować się na rzecz kasy konsystorskiej, co nie spotkało się z akceptacją stołecznych protestantów ${ }^{73}$.

W maju 1781 r. wielkopolski synod prowincjonalny w Lesznie, mimo wątpliwości duchownych dotyczących nowego prawa kościelnego, uznał, że decyzje w tej sprawie należą do synodu generalnego. Nie przeszkodziło to Wielkopolanom zaakceptować regulację $e^{74}$.

Konflikt w sprawie zbioru praw kościelnych ujawnił się na prowincjonalnym synodzie małopolsko-mazowieckim w Sielcu. Obradował on w dniach 14-18 czerwca 1781 r., a funkcję dyrektora pełnił pułkownik Samuel Ożarowski ${ }^{75}$. Powołano sześcioosobową komisję do przestudiowania prawa kościelnego pod kątem zgodności z ustawodawstwem Rzeczypospolitej i aktem unii sieleckiej, której nienaruszalność silnie podkreślono. Komisarze powinni uwzględnić jedynie te przepisy prawa kościelnego, które uznano za zgodne ze specyfiką prowincji małopolsko-mazowieckiej. Miał je rozważyć i potwierdzić kolejny synod prowincjonalny w Sielcu ${ }^{76}$. De facto było to wycofanie się przez prowincję małopolsko-mazowiecką z akceptacji prawa kościelnego. Podniesiono też problem kompetencji A. Unruga jako seniora generalnego, gdyż sprawa ta nie była przewidziana w instrukcji dla delegatów synodu sieleckiego. Wobec braku uregulowań synodu generalnego uznano, że prowincje mogą same określać jego uprawnienia w stosunku do swojej Jednoty. Wyliczono sprawy, w które senior generalny trzech prowincji nie powinien ingerować. Zastrzegano, że w sprawach grawaminów i naruszeń traktatów powinien współdziałać z pełnomocnikami prowincji. Nie mógł on także: 1) kierować not i suplik, jeśli nie były zaakceptowane na synodzie prowincjonalnym;2) zabiegać o przywileje królewskie dla asesorów; 3) zwoływać synodu generalnego bez zgody seniorów trzech prowincji; 4) zwoływać synodów prowincjonalnych oraz ingerować w działalność konsystorzy i zborów ${ }^{77}$. Seniorzy stanu rycerskiego mieli korespondować z dyrektorem synodu generalnego w sprawie terminu reasumpcji zalimitowanych obrad, na które wybrano delegatów ${ }^{78}$. $\mathrm{Z}$ innych spraw w Sielcu m.in.: 1) zakazano łączenia godności seniora duchownego z funkcją w konsystorzu; 2) zakwestionowano możliwość wydawania wyroków extra cadentiam przez konsystorz warszawski; 3) odrzucono propozycję seniora

73 W. Gastpary, op. cit., s. 79-80.

74 Ibidem, s. 84

75 Akta i uchwały synodu wspólnego prowincji małopolskiej z księstwem mazowieckim... $1781 \mathrm{w}$ Sielcu, BCz 753, s. 593.

76 Akta i uchwały synodu... 1781 w Sielcu, BCz 753, s. 597-600; W. Gas s par y, op. cit., s. 81.

77 Akta i uchwały synodu... 1781 w Sielcu, BCz 753, s. 600-604; W. Gas tpa ry, op. cit., s. 82.

78 Akta i uchwały synodu... $1781 \mathrm{w}$ Sielcu, BCz 753, s. 605, 613-614. 
stanu mieszczańskiego, by synody prowincjonalne odbywały się alternatą w Małopolsce i w Warszawie. Dokonano też zmian w składzie konsystorza ${ }^{79}$.

Wśród luteranów warszawskich powstały kontrowersje między zwolennikami tradycyjnej agendy saskiej, popieranymi przez ks. G. Ringeltaube, a obrońcami unii sieleckiej reprezentowanymi przez kolegium kościelne i ks. Fryderyka Cerullego. Zwolennicy agendy saskiej szukali poparcia u O. von Stackelberga, a A.S. Goltz i A. Unrug doprowadzili do zawieszenia ks. F. Cerullego w jego obowiązkach i zakazania mu odprawiania nabożeństw ${ }^{80}$.

Pułkownik Kauffmann, współdziałający z A.S. Goltzem i A. Unrugiem, złożył w lutym 1782 r. pozwy przeciwko: unii sieleckiej z 1777 r., synodowi w Sielcu z 1781 r., wspólnemu konsystorzowi w Warszawie, stołecznemu kolegium kościelnemu, a także różnym osobom, m.in. ks. F. Cerullemu ${ }^{81}$. Odpowiedzią były manifesty, z którymi w marcu przeciwko Kauffmannowi wystąpili: znany drukarz Michał Gröll, Karol L. Kortum, Michał Sattler, doktor medycyny Grzegorz Chrystian Arnold i kupiec Chrystian Ebert ${ }^{82}$.

Sporami zajął się zwołany doraźnie luterański partykularny synod mazowiecki w Warszawie. Rozpoczął się 22 kwietnia i debatował z przerwami - obrady były limitowane - do 18 maja 1782 r. ${ }^{83}$ Rzecz niezwykła, decyzję o jego zwołaniu podjął Stanisław August, wydając reskrypt z 6 kwietnia 1782 r. Króla na obradach reprezentował pułkownik Kauffmann. Rozpatrywano skargi na warszawskie kolegium kościelne, które z kolei kwestionowało zasadność zgromadzenia. Jego członków skazano zaocznie, gdyż opuścili obrady, na utratę godności kościelnych. Powołano odrębny konsystorz luterański ${ }^{84}$.

Równolegle w Sielcu obradował nadzwyczajny synod małopolsko-mazowiecki, który miał zająć stanowisko w sprawach przewidzianych do dyskusji na synodzie generalnym

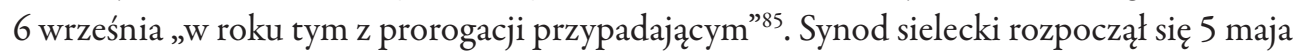
1782 r. Na dyrektora wybrano szambelana Pawła Stryjeńskiego. Do Sielca przybyli delegaci warszawscy obojga wyznań, którzy zostali powitani na sesji 6 maja przez pułkownika J. Malickiego, seniora „stanu rycerskiego" ${ }^{6}$. W obrady synodu ingerował ambasador O. von Stackelberg, którego list z 3 maja, przekazany przez przedstawicieli stołecznego zboru

79 Ibidem, s. 607-608, 610-611; W. Gastpary, op. cit., s. 83-84.

80 W. Smoleńs ki, op. cit., s. 45-46; W. Gastpary, op. cit., s. 87-90.

81 W. Gast pary, op. cit., s. 89.

82 Konotacja następujących pism prawnych... w interesie dysydenckim, BCz 756, s. 169, 221-235.

83 Protocoll über Den Particulair Synod im Herzogthum Masuzen ao: 1782 gehalten wie nachstehend folget, AGAD, ZEAW 13, s. 1-43.

84 Reskrypt Stanisława Augusta z 6 IV 1782, AGAD, ZEAW 13, s. 61-63; W. S moleń ski, op. cit., s. 46; W. Gastpary, op. cit., s. 90-91.

85 Akt limity synodu w Sielcu z 8 V 1782, AGAD, ZEAW 13, s. 126-127.

86 Diariusz synodu ekstraordynaryjnego prowincjalnego prowincji małopolskiej złączonej z księstwem mazowieckim... w Sielcu, AGAD, ZEAW 13, s. 130-132. 
luterańskiego, został odczytany w drugim dniu obrad ${ }^{87}$. Poseł imperatorowej żądał, aby synod, idąc za przykładem protestantów wielkopolskich, przyjął księgę praw kościelnych i zaakceptował prerogatywy seniora generalnego trzech prowincji. W przeciwnym wypadku ambasador zapowiadał nieważność obrad i niełaskę Katarzyny $\mathrm{II}^{88}$. W centrum uwagi znalazła się sytuacja w zborze warszawskim. W tej sprawie kapitan Filip Stettner skierował list do synodu (odczytany 7 maja). Swoje skargi przedstawił obradującym ks. F. Cerulli. Nie zajęto się jednak sprawą ze względu na ostrzeżenie, które skierował w tej kwestii O. von Stackelberg ${ }^{89} .7$ maja przedstawione zostały przesłane na piśmie żądania kupca Ch. Eberta i doktora medycyny G.Ch. Arnolda - te w sprawach kościelnych odesłano do wspólnego konsystorza warszawskiego, w kwestiach cywilnych natomiast do odpowiedniego sądu świeckiego ${ }^{90}$. Na synodzie sieleckim w 1779 r. Ebert i Arnold byli wybrani delegatami „stanu cywilnego" na synod generalny ${ }^{91}$. Na sesji 8 maja 1782 r. synod podjął decyzję o limicie obrad, aby przedstawić swoje stanowisko ambasadorowi. Przygotowano też odpowiedź na jego list ${ }^{92}$. Synod sielecki powołał się na instrukcję dla delegatów na synod generalny w 1780 r., która zakładała w sprawach decyzji podejmowanych w Węgrowie „referencję” do synodu prowincjonalnego. Co do kompetencji generalnego seniora trzech prowincji zaznaczono, że w kanonie synodu generalnego o jego „jurysdykcji nad nami” nie ma mowy; „jednak jegoż prerogatiwę naszemi prowincjalnego synodu kanonami stwierdzamy" W sprawie księgi praw kościelnych uznano, że nie można jej przyjąć bez naruszenia praw króla i kraju. W akcie limity obrad potwierdzono wszystkie decyzje podjęte na małopolsko-mazowieckim synodzie prowincjonalnym w poprzednim roku' ${ }^{95}$.

Członkowie stołecznego luterańskiego kolegium kościelnego i reprezentanci zboru złożyli 25 czerwca 1782 r. manifest ukazujący zagrożenia dla życia kościelnego wynikające z konfliktów wśród ewangelików augsburskich. Sytuacją w zborze luterańskim zaniepokojeni byli także warszawscy reformowani, którzy latem 1782 r. ogłosili w aktach grodzkich manifest przeciwko powołaniu odrębnego konsystorza luterańskiego ${ }^{96}$.

Obrady zalimitowanego synodu prowincjonalnego kontynuowano w Sielcu w dniach 14-17 sierpnia 1782 r. Przyjęto m.in. uchwałę dotyczącą powołania pełnomocników,

${ }_{87}$ Akta synodu ekstraordynaryjnego... w Sielcu... i diariusz synodu ekstraordynaryjnego..., AGAD, ZEAW 13, s. 122, 132.

88 Akt limity, AGAD, ZEAW 13, s. 127.

89 Diariusz synodu ekstraordynaryjnego..., AGAD, ZEAW 13, s. 132-133.

$90 \quad$ Ibidem, s. 133.

91 Akta i uchwały synodu... w Sielcu... 1779, AGAD, ZEAW 12, s. 52.

92 Akt limity, BUW 600, s. 69-70; W. Gast pa ry, op. cit., s. 92.

93 Akt limity, AGAD, ZEAW 13, s. 127-128 (także: BUW 600, s. 69).

94 Ibidem, s. 128 (także: BUW 600, s. 69); W. Gastpar y, op. cit., s. 92-93.

95 Akt limity, BUW 600, s. 70 (także: AGAD, ZEAW 13, s. 128-129).

96 W. Gastpary, op. cit., s. 93-94. 
którzy mieli przeciwdziałać wymierzonym w prowincję małopolsko-mazowiecką poczynaniom pułkownika Kauffmanna, a także podjąć wobec niego czynności prawne. Wybrano też dodatkowych delegatów na synod generalny ${ }^{97}$. Uchwalona została instrukcja dla przedstawicieli prowincji małopolsko-mazowieckiej w Węgrowie. Domagano się pozbawienia prawa głosu na synodzie generalnym osób, które nie miały plenipotencji właściwego synodu prowincjonalnego, co było wymierzone w reprezentantów partykularnego synodu mazowieckiego. Decyzje na synodach generalnych miały zapadać według zasady jednomyślności prowincji, przy czym w praktyce o przyjęciu przepisów prawnych obowiązujących w danej Jednocie decydowałby synod prowincjonalny. Domagano się także uchylenia księgi praw kościelnych jako niezgodnej z obowiązującymi ustawami ${ }^{98}$.

Powyższymi sporami zajął się synod generalny w Węgrowie. Powinien się on rozpocząć 6 września 1782 r. pod kierunkiem A.S. Goltza, gdyż była to kontynuacja synodu generalnego zalimitowanego w 1780 r. Faktycznie jednak obrady zaczęły się dwa dni później99. Delegaci synodu sieleckiego protestowali przeciwko udziałowi w zgromadzeniu reprezentantów partykularnego synodu mazowieckiego. Unrug podważał ważność unii sieleckiej, zaś A.S. Goltz uzasadniał zwołanie i ważność uchwał odrębnego synodu mazowieckiego ${ }^{100}$. Zwolennicy unii z 1777 r. wytykali A.S. Goltzowi szykany wobec prowincji małopolsko-mazowieckiej, której wszystkie wnioski były odrzucane, a mandaty jej przedstawicieli kwestionowane. Zarzucano dyrektorowi m.in. brak zgody na ułożenie porządku synodowania, co popierali przedstawiciele wszystkich prowincji. Tak przynajmniej twierdzili autorzy manifestu. Zwolennicy unii sieleckiej skarżyli się na straszenie ich niełaską Katarzyny II i przypisywanie im działań przeciwko uprawnieniom królewskim ${ }^{101}$. Na synod obok pułkownika Kauffmanna, reprezentującego Stanisława Augusta, przybył także pułkownik P. Königfels, wydelegowany przez O. von Stackelberga. Zalecał on synodowi ograniczenie się do unii wyłącznie „politycznej”102. Kauffmann odczytał przysłany sztafetą list królewski, w którym Stanisław August krytycznie odnosił się do dotychczasowego przebiegu obrad. Kauffmann oświadczył, że jeśli wszyscy delegaci nie mogą dojść do porozumienia, niech uczynią to przynajmniej przedstawiciele wyznania ewangelicko-augsburskiego ${ }^{103} .17$ września doszło do rozłamu w synodzie. Goltz podjął decyzję o odrębnych obradach obu konfesji. Poparli go wielkopolscy luteranie, przedstawiciele partykularnego

\footnotetext{
97 Akta i uchwały synodu wspólnego... d. 14 aug. rozpoczętego... w Sielcu 1782 roku, BUW 600, s. 71, 75-76.

98 Instrukcja na synod generalny... dana w Sielcu d. 16. augusta 1782 roku, BUW 603, k. 33-34v.

99 Manifest Jana Malickiego, Pawła Stryjeńskiego, Stanisława Ożarowskiego i innych z 18 IX 1782 (oblatowany w grodzie liwskim), BCz 756, s. 260; W. G as t p a r y, op. cit., s. 94-95.

100 W. Gastpary, op. cit., s. 95-96.

101 Manifest... z 18 IX 1782, BCz 756, s. 260-261.

102 W. Gastpary, op. cit., s. 96.

103 Ibidem, s. 97.
} 
synodu mazowieckiego i dwie osoby wyznania augsburskiego przysłane przez litewski synod w Birżach. Przeciwni temu byli delegaci z Małopolski i Litwy (obu wyznań) i wielkopolscy reformowani ${ }^{104}$. Delegaci synodu sieleckiego opuścili obrady i zapowiadali, że nie podporządkują się uchwałom podjętym pod ich nieobecność. Zwolennicy unii sieleckiej oblatowali 18 września 1782 r. w grodzie liwskim manifesty, m.in. ujęte w siedmiu punktach zarzuty przeciwko czynnościom synodu oraz poczynaniom A.S. Goltza. Kwestionowano także księgę praw kościelnych ${ }^{105}$.

Kilka dni później odrębne zgromadzenie stworzyli delegaci wyznania luterańskiego. Zwolennicy A.S. Goltza obradowali w dniach 21-28 września 1782 r. jako synod ewangelicko-augsburski. Zajęto się sporami w zborze warszawskim. Co do sytuacji na Litwie, nie zakwestionowano wprawdzie unii „politycznej” obu wyznań, ale za obowiązujące dla luteranów uznano decyzje podjęte na synodzie w Birżach ${ }^{106}$. Wydarzenia z września $1782 \mathrm{r}$. oznaczały koniec unii sieleckiej w dotychczasowym kształcie ${ }^{107}$, a przede wszystkim rezygnację z idei odbywania wspólnych dla ewangelików obu wyznań synodów generalnych. Późniejsze funkcjonowanie protestanckich struktur kościelnych to temat wymagający jeszcze badań. W artykule ograniczę się do omówienia politycznych reperkusji dalszych sporów.

Na sesji Rady Nieustającej z 22 listopada 1782 r. została odczytana nota O. von Stackelberga (z 18 listopada) zawierająca żądanie, by przy egzekucji protestanckich dekretów synodalnych i konsystorskich dodawana była pomoc wojskowa ${ }^{108}$. Poseł rosyjski przytaczał także zażalenia dysydentów dotyczące naruszeń traktatu z 1768 r. Chodziło o przepisy stwierdzające, że w sądach pierwszej instancji powinny być ustanowione osobne regestry dla spraw dotyczących wolności religii protestanckich, które to sprawy miały być sądzone przed innymi sprawami cywilnymi. W postępowaniu dotyczącym wyznań ewangelickich przewidywano udział, obok sędziów katolickich, także „subdelegowanych” sędziów dysydenckich. Wyroki sądów pierwszej instancji w sprawach protestantów, które dotyczyły religii, powinny być ostateczne, co jednak w praktyce nie było stosowane. Ambasador domagał się skierowania uniwersału do sądów koronnych i litewskich z zaleceniem przestrzegania powyższych zasad ${ }^{109}$.

Na sesji Rady Nieustającej 26 listopada 1782 r., przed prezentacją zdania Departamentu Sprawiedliwości w sprawie zażaleń dysydentów, głos zabrał biskup Józef Kossakowski.

104 Manifest... z 18 IX 1782, BCz 756, s. 262-263.

105 Konotacja następujących pism prawnych... i manifest... z 18 IX 1782, BCz 756, s. 169-170, 259-263.

106 W. Gastpary, op. cit., s. 99-101.

107 W późniejszych synodach prowincji małopolskiej nie brali udziału reprezentanci zborów warszawskich. W synodzie małopolskim 25-26 września 1784 r. uczestniczył delegat luterańskiego zboru w Lublinie. Akta i uchwały synodu... w Sielcu d. 25 i $267^{\text {bris }} 1784$, BUW 599, k. 25, 27v.

108 Protokół Rady Nieustającej z 22 XI 1782, AGAD, ML VII/45, s. 24.

109 Ibidem, s. 24-25. 
Biskup inflancki stwierdzil, że ustawy niektórych synodów protestanckich przewidują w kwestiach religii jedynie „kary duchowne”, a nie cywilne. Przyjęta na synodzie w Węgrowie księga praw napisana przez H.G. Scheidemantla wykracza poza zakres wolności przyznanej dysydentom $w$ traktatach i jest $w$ wielu sprawach sprzeczna $\mathrm{z}$ obowiązującym ustawodawstwem ${ }^{110}$. Rada Nieustająca powinna zastanowić się, jak zapobiec szerzeniu się „zamieszania wewnętrznego" wśród ewangelików, a także próbom przywłaszczania sobie władzy tworzenia „legislacji cywilnej”, co grozi powstaniem państwa w państwie. Jako przykład biskup inflancki podał sprawę „sztemplów i tytułów”, co było przyczyną sporów wśród samych protestantów ${ }^{111}$. Wiadomo też, że memoriał, wyliczający przykłady niezgodności księgi praw kościelnych z przepisami prawa powszechnego, skierowali do kanclerza koronnego dysydenci warszawscy ${ }^{112}$. Po przeczytaniu stanowiska Departamentu Sprawiedliwości Kazimierz Raczyński, marszałek Rady Nieustającej, poinformował konsyliarzy o dostarczonym mu memoriale Stanisława Ożarowskiego i Naxa [?], plenipotentów ewangelików prowincji małopolskiej. W tej sytuacji Rada Nieustająca postanowiła odłożyć stanowisko Departamentu „do dalszej deliberacji”113.

W grudniu 1782 r. Stanisław August pisał z niepokojem do Augustyna Debolego, polskiego dyplomaty w Petersburgu, że Rada Nieustająca może zająć stanowisko niezgodne z życzeniami O. von Stackelberga. Według monarchy rosyjski ambasador działał pod wpływem A.S. Goltza i A. Unruga. Król twierdził, że konsyliarze Rady „zacinają się w swoim zdaniu”. Ich opór wzmagał zaś fakt, iż inspirowanie zabiegów ambasadora przypisywano „niespokojnemu duchowi” wojewody poznańskiego Augusta Sułkowskiego ${ }^{114}$.

Aby zakończyć konflikty wśród protestantów, Stanisław August pod wpływem O. von Stackelberga wyznaczył na mediatorów wojewodów poznańskiego A. Sułkowskiego i mazowieckiego Andrzeja Mokronowskiego oraz podkanclerzego litewskiego Joachima Chreptowicza. Udało się im doprowadzić do podpisania 29 stycznia 1783 r. ugody, w której stwierdzono, że unia sielecka, jako „polityczna”, nie może ograniczać samodzielności Kościołów, co miało się wyrażać m.in. w odrębnych synodach i konsystorzach ${ }^{115}$.

Do kwestii odpowiedzi na notę O. von Stackelberga w sprawie dysydenckiej wrócono na wniosek kanclerza koronnego Antoniego Onufrego Okęckiego na sesji Rady Nieustającej

110 Protokół Rady Nieustającej z 26 XI 1782, AGAD, ML VII/45, s. 35. J. Kossakowski często współpracował ze Stackelbergiem, ale ambasador był wówczas niezadowolony z postawy biskupa w sprawie dysydentów. Pamiętniki Józefa Kossakowskiego, biskupa inflanckiego 1738-1788, wyd. A. Da rowski, Warszawa 1891, s. 144.

111 Protokół Rady Nieustającej z 26 XI 1782, AGAD, ML VII/45, s. 35-36.

112 Akta i korespondencja królewska w związku z synodem w Węgrowie 1782, BCz 757, s. 167-169.

113 Protokół Rady Nieustającej z 26 XI 1782, AGAD, ML VII/45, s. 36.

114 Stanisław August do A. Debolego, 16 XII 1782, [w:] Korespondencja polityczna Stanistawa Augusta. Augustyn Deboli 1782, oprac. E. Zielińska, A. Danilczyk, Warszawa 2017, s. 321-322.

115 W. S moleński, op. cit., s. 46-47. 
11 kwietnia 1783 r. ${ }^{16}$ Departament Sprawiedliwości przedstawił projekt uniwersału „względem otworzenia regestrów i kadencji sądowych dla spraw dysydenckich". Został on przyjęty przez Radę Nieustającą, która nakazała go rozesłać „do prowincji obu narodów”"117. Na sesji z 29 kwietnia 1783 r. odczytano przygotowaną przez Departament Interesów Cudzoziemskich notę do posła rosyjskiego z informacją o wysłaniu do sądów pierwszej instancji w Koronie i na Litwie uniwersału w sprawie „utworzenia regestru dla spraw dysydenckich”"18.

Wkrótce powstał kolejny konflikt - w sprawie druku książki religijnej, do której nabywania (za 8 zł) zobowiązano wszystkich luteranów. Protestowano, że była to ukryta forma opodatkowania, gdyż egzekwowano opłatę w drodze wyroków konsystorskich ${ }^{119}$.

W styczniu 1784 r. Stanisław August skarżył się A. Mokronowskiemu na upór kanclerza A.O. Okęckiego (wojewoda mazowiecki był jego wujem) w sprawie dysydenckiej. Chodziło o jego postawę w Asesorii. Król obawiał się, że postępowanie pieczętarza narazi kraj na odwetowe kroki Rosji, a kanclerza na wrogość O. von Stackelberga ${ }^{120}$. W lipcu tegoż roku król informował J. Chreptowicza, że rosyjski ambasador domagał się „renowacji” konsystorza luterańskiego na podstawie reskryptu królewskiego. Spotkało się to jednak z oporem kanclerza koronnego domagającego się wyjaśnień w tej sprawie. Stanisław August przypomniał Stackelbergowi, że konsystorz powinien być wybrany na synodzie, który w tym roku się nie odbył. Mogło to stworzyć ewangelikom warszawskim pretekst do nieposłuszeństwa wobec decyzji konsystorza. Z odpowiedzi rosyjskiego dyplomaty wynikało, że synodu nie zwołano, gdyż takie stanowisko zajęli Stackelberg, Goltz i Unrug. Monarcha deklarował, że postąpi zgodnie z oczekiwaniami Rosji, a ambasador zgodził się wysłać do Okęckiego „eksplikatorów” swoich racji121.

$\mathrm{Na}$ sesji 24 sierpnia $1784 \mathrm{r}$. Rada Nieustająca wydała rezolucję w odpowiedzi na noty Stackelberga z zażaleniem na kontumacyjny dekret Asesorii Koronnej z 29 marca 1784 r. w sprawie między „niektóremi mieszczanami warszawskiemi” a szlachtą luterańską. Ambasador uważał wyrok za sprzeczny z traktatami z 1768 i 1775 r. Treść dekretu wynikała z tego, że pozwani przez mieszczan komisarze konsystorza nie uznali Asesorii za właściwe forum i nie wzięli udziału w rozprawie. Ambasador domagał się też, by Departament Wojskowy udzielał pomocy wojskowej przy egzekucji wyroków synodów i konsystorzy dysydenckich ${ }^{122}$.

116 Protokół Rady Nieustającej z 11 IV 1783, AGAD, ML VII/45, s. 247.

117 Projekt do uniwersału względem otworzenia regestrów i kadencji sądowych dla spraw dysydenckich, AGAD, ML VII/91, s. 533-534; Protokół Rady Nieustającej z 11 IV 1783, AGAD, ML VII/45, s. 247248.

118 Protokół Rady Nieustającej z 29 IV 1783, AGAD, ML VII/45, s. 258.

119 W. Smoleński, op. cit., s. 47.

120 Król do A. Mokronowskiego z 30 I 1784, BCz 927, s. 885-887.

121 Król do J. Chreptowicza z 17 VII 1784, BCz 724, s. 269-271.

122 Protokół Rady Nieustającej z 24 VIII 1784, AGAD, ML VII/52, k. 81-81v; W. Filipcza k, Życie sejmikowe..., s. 118. 
Rezolucja z 24 sierpnia 1784 r. stała się obiektem krytyki na sejmie grodzieńskim. Na sesji 20 października 1784 r. poseł kaliski Józef Wybicki, występujący jako delegowany do kontroli Rady Nieustającej, sugerował, że decyzja magistratury była podyktowana okolicznościami niosącymi zagrożenie, tzn. naciskiem ze strony Rosji. Stwierdzał, że można egzekwować „mocą cywilną” decyzje w sprawach obrządków religijnych. Za „utajony gwałt” uznawał jednak zmuszanie, z użyciem pomocy wojskowej, do płacenia dodatkowego podatku pod pozorem zbierania różnych składek kościelnych ${ }^{123}$. Do tematu wrócił poseł gnieźnieński Stanisław Breza, już po rozłączeniu się izb, na sesji 25 października. Uznał on za konieczne, ze względu na „przyjaźń” imperatorowej, dotrzymanie traktatu z Rosją także w tym, co dotyczy „wolności dysydentów”. Jednak rezolucję Rady przewidującą udzielanie pomocy wojskowej w sytuacji, gdy synod narzuca kontrybucję na poddanych, uznał za szkodliwą dla interesów finansowych szlachty i kraju. Breza złożył w tej sprawie projekt „do laski"124. Jeszcze na tej sesji został on odczytany na żądanie wielu posłów ${ }^{125}$.

Projekt ponownie wrócił pod obrady na sesji 27 października, spotkał się jednak z opozycją wielu parlamentarzystów ze względu na dokonane w nim zmiany. Poseł poznański Ignacy Moszczeński domagał się odczytania go ponownie w pierwotnej wersji. Poseł inflancki Antoni Suffczyński twierdził jednak, że skoro projekt skierowano do deliberacji, nie ma nic niewłaściwego $\mathrm{w}$ tym, że został zaprezentowany $\mathrm{w}$ poprawionej formie ${ }^{126}$. Zmian w projekcie dokonał zapewne Stanisław August, który - jak można się domyślać starał się uwzględnić stanowisko O. von Stackelberga. W pierwotnej wersji projektu zastrzegano, że rezolucja z 24 sierpnia 1784 r. nie może być stosowana do nakładania przez synody lub konsystorze „na osoby tychże religii datków” i w takich sprawach nie powinna być udzielana pomoc wojskowa. Po słowie „datków” skreślone zostało zastrzeżenie, że nie dotyczy to świadczeń na utrzymanie „wewnętrznego porządku tym religiom służącego” i dozwolonych przez prawo traktatowe. Zamiast tego wprowadzono sformulowanie dopuszczające stosowanie rezolucji z 24 sierpnia w odniesieniu do opłat na utrzymanie zborów, pastorów oraz „sług kościelnych”, jeśli protestanci w królewszczyznach zaakceptowali je dobrowolnie, a w dobrach szlacheckich za wiedzą dziedziców zobowiązali się do ich płacenia „przez konwencje na piśmie” ${ }^{127}$. Dalej regulowano tryb egzekwowania zaległości w tym zakresie, przewidując także użycie pomocy wojskowej. Zastrzegano możliwość od-

123 Dyaryusz Seymu wolnego ordynaryinego... 1784..., wyd. M. Tukalski-Nielu bow icz, Warszawa 1785 [dalej: Diariusz 1784], s. 72; J. Wy bicki, Mowa... na Seym walny grodzieński... 20 X 1784..., [w:] Zbior mow w czasie Seymu szescio-niedzielnego roku 1784 mianych $w$ Grodnie, Wilno, b.d. [dalej: ZM 1784], s. 208.

124 Diariusz 1784, s. 337-338; s. Breza, Gtos...na Seymie walnym grodzieńskim... 25. [X] 1784 miany, [w:] ZM 1784, s. 402-403.

125 Diariusz 1784, s. 342.

126 Ibidem, s. 360, 363.

127 Rezolucja Rady Nieustającej pod dniem 24 sierpnia..., AGAD, ZP 128, k. 190-190v. 
wołania się od decyzji władz kościelnych („forum taka sprawa in judicio composito w Asesorii mieć będzie") ${ }^{128}$.

Do dyskusji nad projektem posłowie wrócili 28 października 1784 r. Po jego odczytaniu poseł wołkowyski J.J. Grabowski (ewangelik reformowany) wniósł poprawkę, by po słowie „dysydentów” dodać „augustanae confessionis”. Z powyższą zmianą projekt został przyjęty jednomyślnie w izbie poselskiej i senacie ${ }^{129}$.

Jesienią 1785 r. w Wielkopolsce miały miejsce spory między dysydencką szlachtą z jednej strony i „pospólstwem” protestanckim z drugiej. Budziły one niepokój jednego z liderów wielkopolskich regalistów Franciszka Ksawerego Kęszyckiego. Kasztelan kaliski (później wojewoda gnieźnieński) obawiał się, że katolicka szlachta, solidaryzując się z mieszkającym w jej dobrach dysydenckim „pospólstwem”, może forsować w przyszłej instrukcji poselskiej postulaty godzące w ewangelickich ziemian ${ }^{130}$. Stanisław August uważał, że sytuacja w Wielkopolsce była pochodną konfliktu warszawskiego. Szlacheccy seniorzy luterańscy byli oskarżani przez warszawskich współwyznawców o arbitralne narzucanie mieszczanom dodatkowych obciążeń finansowych. Stołeczni luteranie upowszechniali w tej sprawie drukowaną broszurę, która wpływała także na sytuację w województwach wielkopolskich ${ }^{131}$. Chodziło m.in. o zakres kompetencji władz kościelnych. W konsystorzu zapadł bowiem wyrok skazujący kolegium kościelne w sprawie dotyczącej przedstawianych rachunków. Odwołano się od wyroku do Asesorii i do sądu grodzkiego $^{132}$. W obronie pozycji synodów i konsystorzy występował O. von Stackelberg, który powoływał się na postanowienia traktatowe. Poseł rosyjski straszył króla, że z konfliktu może wyniknąć „druga barska rewolucja i klęska na kraj nasz”. Ambasador uważał, że „trzeba dać się też wygadać i mieszczankom”. Stanisław August zalecał Kęszyckiemu hamowanie niezadowolenia luterańskich mieszczan wielkopolskich. Król sugerował, że w sprawie maczały palce Prusy, które chętnie widziałyby u siebie niezadowolonych dysydenckich mieszczan ${ }^{133}$.

W grudniu 1785 r. O. von Stackelberg skierował notę do Rady Nieustającej, w której oskarżył luterańskich mieszczan o bezzasadne pretendowanie do „równości” ze szlachtą protestancką. Według rosyjskiego dyplomaty nie mogli oni mieć większych praw niż mieszczanie katoliccy. Żądał, żeby protestanci warszawscy byli posłuszni decyzjom synodów i konsystorzy. Ambasador ponownie domagał się udzielania pomocy wojskowej,

128 Diariusz 1784, s. 379; VL, t. IX, Kraków 1889, s. 11. Ostrzeżenie względem rezolucyi Rady na sessyi nro $169 \ldots$

129 Diariusz 1784, s. 378-379.

130 F.K. Kęszycki do króla z 10 XI 1785, BCz 733, s. 203-204; W. Fil i p cz a k, Życie sejmikowe..., s. 256.

131 Król do F.K. Kęszyckiego z 21 XI 1786, BCz 733, s. 205-206.

132 Nota o sprawie dysydenckiej z 2 XII 1785, BCz 932, s. 789-790; W. Fili pczak, Życie sejmikowe..., s. 152.

133 Król do F.K. Kęszyckiego z 21 XI 1786, BCz 733, s. 206-208; W. Fil i p cza k, Życie sejmikowe.., s. 256. 
zgodnie z rezolucją z 1784 r., przy egzekucji dekretów synodalnych i konsystorskich ${ }^{134}$. Rada Nieustająca zajęła się sprawą na sesjach 30 grudnia 1785 i 3 stycznia 1786 r., kiedy wydała uniwersał, w którym postanawiała, że w kwestiach odnoszących się do subordynacji kościelnej obowiązują wyroki jurysdykcji duchownych. Sądy cywilne miały odsyłać im akta spraw w tym zakresie ${ }^{135}$. Król twierdził w liście do A. Debolego, że treść uniwersału była zgodna z żądaniami O. Stackelberga ${ }^{136}$.

Niepokój Kęszyckiego w początkach 1786 r. budziły działania wojewody kaliskiego Antoniego Sułkowskiego. Był on niezadowolony z decyzji króla w sprawie wakującego po śmierci brata Augusta regimentu. Być może, aby utrudnić działania wielkopolskim regalistom, próbował on wykorzystać spory wśród protestantów. Chciał ogłosić manifest współgrający z memoriałem mieszczan warszawskich do Rady Nieustającej, który poparly też wielkopolskie miasta nadgraniczne ${ }^{137}$. Manifest dotyczył niepokojących wielkopolskich mieszczan działań przedstawicieli szlachty dysydenckiej, która organizowała zakazane prawem „prywatne schadzki”. Luteranin Szarzyński i kalwinista Mojaczewski zbierali „po domach” podpisy, by realizować swoje projekty „ukryte przed publicznością”138.

W kwietniu 1786 r. doszło do kolejnej interwencji rosyjskiego ambasadora, niezadowolonego z decyzji Asesorii Koronnej w sprawie sporów warszawskich luteranów ze szlachtą. Zgodnie z opinią kanclerza A.O. Okęckiego sprawę jednogłośnie uznano za cywilną ${ }^{139} . \mathrm{Na}$ sesji Rady z 11 kwietnia 1786 r. odczytano notę O. von Stackelberga z zażaleniem na decyzję sądu. Ambasador twierdził, iż zajął się on kwestią leżącą w kompetencji konsystorza i zwierzchności duchownej. Rada zaleciła Departamentowi Interesów Cudzoziemskich, by poinformował posła rosyjskiego, że sprawę odesłano do Sądu Relacyjnego, który miał ją rozstrzygnąć 19 kwietnia ${ }^{140}$. Rozwiązanie to podkanclerzy Jacek Małachowski uzgodnił z ambasadorem. Król był niezadowolony z zamieszania wokół dysydentów i zaniepokojony interwencją rosyjską na rzecz szlachty luterańskiej. Ustąpił wobec gróźb O. von Stackelberga, straszącego zaborem dwóch kolejnych województww ${ }^{141}$. Monarcha liczyl, że dekret Sądu Relacyjnego zakończy spór. Stanisław August polecał A. Debolemu zbadać, jakimi

\footnotetext{
134 Protokół Rady Nieustającej z 30 XII 1785, AGAD, ML/56, k. 50-50v.

135 Uniwersał Rady Nieustającej z 3 I 1786, AGAD, Sieradzkie grodzkie relacje, sygn. 173, k. 838; Protokół Rady Nieustającej z 3 I 1786, AGAD, ML/56, k. 52-52v; W. Filipcz a k, Życie sejmikowe..., s. 152.

136 Król do A. Debolego z 11 I 1786, AGAD, Archiwum Królestwa Polskiego, sygn. [dalej: AKP] 378, k. 3-4.

137 F.K. Kęszycki do NN z 23 II i 2 III 1786, BCz 733, s. 239, 245; W. Fil i pcza k, Życie sejmikowe..., s. 261.

138 Kopia memoriału do króla i Rady Nieustającej, BCz 733, s. 249; W. Fili p cza k, Życie sejmikowe..., s. 261. Mojaczewscy należeli w Wielkopolsce do ewangelickiej elity rodzin szlacheckich. W. Kriegseisen, Ewangelicy polscy..., s. 82, 136, 141. Jan Mojaczewski, jako wielkopolski senior „stanu rycerskiego”, podpisał w 1779 r. list do synodu w Sielcu. Kopia listu seniorów wielkopolskich..., AGAD, ZEAW 12, s. 64.

139 Król do A. Debolego z 5 IV 1786, AGAD, AKP 378, k. 41-42v.

140 Protokół Rady Nieustającej z 11 IV 1786, AGAD, ML VII/60, k. 5 v-6.

141 Król do A. Debolego z 5 i 12 IV 1786, AGAD, AKP 378, k. 41-46.
} 
kanałami liderzy szlachty luterańskiej, zwłaszcza A.S. Goltz, uzyskali tak silną protekcję w rosyjskiej stolicy ${ }^{142}$.

Konflikty wśród protestantów interesujące elity polityczne nie znalazły odbicia w instrukcjach poselskich z sierpnia $1786 \mathrm{r}$. Wbrew obawom F.K. Kęszyckiego nie pisano o nich w zaleceniach sejmiku w Środzie ${ }^{143}$ ani w innych znanych mi instrukcjach koronnych. Spory jednak nie ustały i miały ciąg dalszy także w początkach obrad Sejmu Wielkiego ${ }^{144}$.

Niepowodzeniem zakończyła się próba doprowadzenia do bliższej współpracy przedstawicieli wyznań ewangelickich. Górę wzięły rozbieżne interesy poszczególnych środowisk i ambicje ich przywódców. Konflikty występujące wśród ewangelików miały też związek z rosnącymi aspiracjami mieszczaństwa protestanckiego, zwłaszcza warszawskiego. Mieszczanie chcieli odgrywać większą rolę w życiu publicznym. W omawianym okresie przede wszystkim próbowali uzyskać znaczący wpływ na instytucje kościelne. Rozpatrując genezę mieszczańskiego ruchu politycznego w czasach Sejmu Wielkiego, warto pamiętać o doświadczeniach zdobywanych przez delegatów miast w dyskusjach podczas synodów. W dotychczasowych badaniach sprawa ta nie była bowiem wystarczająco eksponowana ${ }^{145}$.

\section{BIBLIOGRAFIA}

\section{Źródła rękopiśmienne:}

Archiwum Główne Akt Dawnych w Warszawie

Archiwum Królestwa Polskiego, sygn. 378;

tzw. Metryka Litewska, dział VII, sygn. 20, 45, 52, 56;

Sieradzkie grodzkie relacje, sygn. 173;

Zbór Ewangelicko-Augsburski w Warszawie, sygn. 12, 13, 15;

Zbiór Popielów, sygn. 126, 128, 129, 130.

Archiwum Państwowe w Poznaniu, Akta Braci Czeskich, sygn. 1984, 2504.

Biblioteka Czartoryskich w Krakowie, rkps 663, 724, 733, 753, 756, 757, 927, 932.

Biblioteka PAU i PAN w Krakowie, rkps 8332.

Lietuvos mokslų akademijos Vrublevskių biblioteka, fondas 139, byla 1254.

\section{Źródła drukowane:}

Dyaryusz Seymu ordynaryinego pod zwiąkiem konfederacyi generalney oboyga narodów agitującego się, wyd. A. Cieciszowski, Warszawa 1776.

142 Król do A. Debolego z 12 IV, 3 V i 20 V 1786, AGAD, AKP 378, k. 43-46, 52-53v, 57-57v. Petersburg nawet rekomendował A.S. Goltza na urząd generała artylerii koronnej.

143 Instrukcja sejmiku w Środzie z 21 VIII 1786, AGAD, ZP 130, s. 231-249.

144 O narzucaniu przez „starszyznę dysydencką” nieuzasadnionych opłat na współwyznawców mówił 29 XI 1788 r. poseł chełmski Wojciech Suchodolski. W. S moleńsk i, op. cit., s. 47.

145 Nie pisała o tym szerzej w swojej monografii K. Zienkowska (Stawetni i urodzeni. Ruch polityczny mieszczaństwa w dobie Sejmu Czteroletniego, Warszawa 1976). 
Dyaryusz Seymu wolnego ordynaryinego... 1784..., wyd. M. Tukalski-Nielubowicz, Warszawa 1785. Korespondencja polityczna Stanistawa Augusta. Augustyn Deboli 1782, oprac. E. Zielińska, A. Danilczyk, Warszawa 2017.

Lietuvos Dzidžiosios Kunigaikštystès seimeliu instrukcijos (1788-1790), parengè R. Jurgaitis, A. Stankevič, A. Verbickienè, Vilnius 2015.

Pamiętniki Józefa Kossakowskiego, biskupa inflanckiego 1738-1788, wyd. A. Darowski, Warszawa 1891. Volumina Legum, wyd. J. Ohryzko, t. VIII, Petersburg 1860; t. IX, Kraków 1889.

Zbior mow w czasie Seymu szescio-niedzielnego roku 1784 mianych w Grodnie, Wilno, b.d.

\section{Opracowania:}

Butterwick R., Polska rewolucja a Kościót katolicki 1788-1792, tłum. M. Ugniewski, Kraków 2012. Danilczyk A., W kregu afery Dogrumowej. Sejm 1786 roku, Warszawa 2010.

Dygdała J., Życie polityczne Prus Królewskich u schytku ich związku z Rzecząpospolitą w XVIII wieku, Warszawa-Poznań-Toruń 1984.

Dymnicka-Wołoszyńska H., Matachowski Antoni, [w:] Polski stownik biograficzny, t. 19, Wrocław 1974. Fijałkowski P., Historia parafii ewangelicko-augsburskiej w Itowie w XVIII-XIX w., „Odrodzenie i Reformacja w Polsce” 1994, t. 38, s. 111-120.

Filipczak W., Ekonomie litewskie w polityce sejmikowej Stanistawa Augusta po upadku Antoniego Tyzenhauza (1780-1783), „Przegląd Nauk Historycznych” R. V, 2006, nr 1(9), s. 235-276.

Filipczak W., Sejm 1778 roku, Warszawa 2000.

Filipczak W., Życie sejmikowe prowincji wielkopolskiej w latach 1780-1786, Łódź 2012.

Gastpary W., Historia protestantyzmu w Polsce od potowy XVIII wieku do pierwszej wojny światowej, Warszawa 1977.

Herbst S., Grabowski Pawet, [w:] Polski stownik biograficzny, t. 8, Wrocław 1960.

Kalenkiewiczówna A., Rozktad partii Tyzenhauza na tle sejmików litewskich, [w:] Ksiega pamiątkowa Kota Historyków Stuchaczy USB w Wilnie, Wilno 1933, s. 121-155.

Kłaczewski W., Zbory różnowiercze w Piaskach i ich patronowie, „Rocznik Lubelski” 1979, t. 21, s. 65-75.

Konopczyński W., Grabowski Jan Jerzy, [w:] Polski stownik biograficzny, t. 8, Wrocław 1960.

Kraushar A., Książe Repnin i Polska w pierwszym czteroleciu panowania Stanistawa Augusta (17641768), t. I-II, Kraków 1900.

Kriegseisen W., Dysydenci i dyzunici w Rzeczypospolitej epoki stanistawowskiej, [w:] Stanistaw August i jego Rzeczpospolita. Dramat państwa, odrodzenie narodu, red. A. Sołtys, Z. Zielińska, Warszawa 2013, s. 51-62.

Kriegseisen W., Ewangelicy polscy i litewscy w epoce saskiej (1696-1763). Sytuacja prawna, organizacja i stosunki międzywyznaniowe, Warszawa 1996.

Kriegseisen W., Zbór ewangelicko-reformowany (kalwiński) w Żychlinie koto Konina, „Odrodzenie i Reformacja w Polsce" 1993, t. 37, s. 103-114.

Kriegseisen W., Zbór kalwiński w Sielcu koto Staszowa, „Odrodzenie i Reformacja w Polsce” 1990, t. 35, s. 157-178.

Łubieńska C., Sprawa dysydencka 1764-1766, Kraków-Warszawa 1911.

Eukowski G.T., The Szlachta and the Confederacy of Radom 1764-1767/68: A Study of the Polish Nobility, Roma 1977.

Michalski J., Sprawa wyboru postów dysydentów na sejm 1776 roku, [w:] Kultura staropolska - kultura europejska. Prace ofiarowane Januszowi Tazbirowi w siedemdziesiata rocznice urodzin, red. S. Bylina, Warszawa 1997, s. 273-280. 
Rudnicki K., Biskup Kajetan Sottyk 1715-1788, Warszawa-Kraków 1906.

Smoleński W., Mieszczaństwo warszawskie w końcu wieku XVIII, wyd. 2, Warszawa 1976.

Szczygielski W., Referendum trzeciomajowe. Sejmiki lutowe 1792 roku, Łódź 1994.

Zając P., Giovanni Andrea Archetti i Stanistaw August Poniatowski. Obraz króla i wzajemnych relacji $w$ depeszach nuncjusza do sekretu stanu Stolicy Apostolskiej z lat 1776-1784, „Kwartalnik Historyczny" R. CXXIII, 2016, nr 2, s. 279-311, https://doi.org/10.12775/KH.2016.123.2.03.

Zielińska Z., Polska w okowach „systemu pótnocnego” 1763-1766, Kraków 2012.

Zienkowska K., Stawetni i urodzeni. Ruch polityczny mieszczaństwa w dobie Sejmu Czteroletniego, Warszawa 1976. 